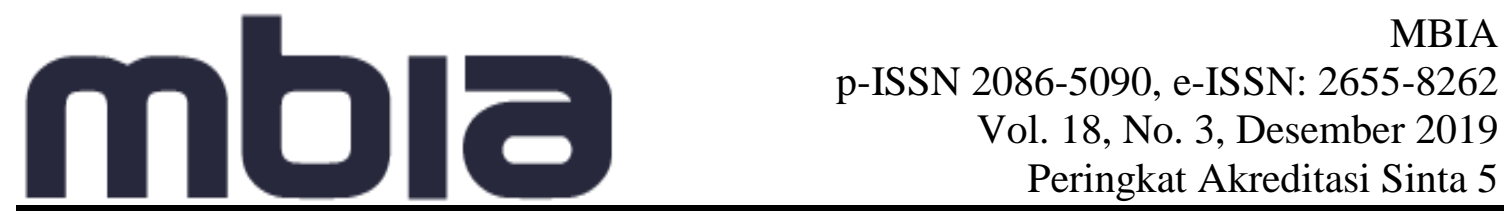

\title{
Keberlanjutan Usaha Kemplang Mikro
}

\author{
Dasir \\ Universitas Muhammadiyah Palembang \\ Email: jatiperahu@yahoo.co.id \\ Erliza Yuniarti \\ Universitas Muhammadiyah Palembang \\ Email:erlizay@yahoo.com \\ Diah Isnaini Asiati \\ Universitas Muhammadiyah Palembang \\ Email:diahisnaini@yahoo.com
}

\begin{abstract}
The business of managing Kerupuk Kemplang as one of Palembang'sspecial foods is mostly managed by household. One of businesss is "Ibu Mai". Although tihis business has been going on for a long time, its sustainability has several obstacles. The study was conducted to find out some aspects that cause its sustainability. The study uses primary data collected through observation and interviews. The analysis technique is done qualitatively with the induction analysis approach. The results were obtained 1) Production aspects, there were constraints on the avaibility of unstable fish and equipment that does not support 2) Financial aspects, adequate financial administration has not been used so it is difficult to know the flow of expenditure and income as a basis for determining profits 3) Market aspects, not all the market can be served so that the potential for development is still large 4) the aspect of human resources, because the production process is simple the labor force is considered to be sufficient.
\end{abstract}

Keywords: production aspects, financial aspects, market aspects, aspect of human resources

\begin{abstract}
Abstrak
Usaha pengelolaan kerupuk kemplang sebagai salah satu makanan khas Palembang banyak dikelola berbasis rumah tangga. Salah satu usaha tersebut adalah "Ibu Mai" Meskipun usaha ini telah berlangsungcukup lama, akan tetapi keberlanjutannya memiliki beberapa kendala. Penelitian dilakukan untuk mengetahui beberapa aspek yang menjadi penyebab keberlanjutannya. Penelitian menggunakan data primer yang dikumpulkan lewat observasi dan wawancara. Teknik analisis dilakukan secara kualitatif dengan pendekatan analisis induksi. Hasil penelitian diperoleh 1) Aspek produksi, terdapat kendala pada ketersediaan ikan yang tidak stabil dan peralatan yang kurang mendukung 2) Aspek keuangan, belum digunakan administrasi keuangan yang memadai sehingga sulit diketahui arus pengeluaran dan pemasukan sebagai dasar penentuan keuntungan 3) Aspek pasar, belum semua pasar dapat dilayani sehingga potensi pengembangannya masih besar 4) Aspek sumberdaya manusia, karena proses produksi sederhana, maka tenaga kerja yang digunakan dinilai telah mencukupi.
\end{abstract}

Kata kunci: aspek produksi, aspek keuangan, aspek pasar, aspek sumberdaya manusia

\section{Pendahuluan}

Makanan berbasis ikan merupakan makanan khas Palembang. Berbagai olahan dapat dibuat dengan bahan baku ikan tersebut, salah satu diantaranya adalah kerupuk kemplang. Pengolahan kerupuk kemplang di desa Pantai Kecamatan Sirah Pulau Padang Kabupaten Ogan Komering Ilir Sumatera Selatan, sebagaimana dilakukan di berbagai daerah dilakukan berbasis rumah tangga (home industry). Usaha yang semula sekedar dilakukan untuk memenuhi kebutuhan ekonomi seperti ini masuk dalam sektor informal, berskala mikro, umumnya terkait dengan kearifan lokal, mengedepankan buatan tangan, tenaga kerja tidak professional, dan bermodal kecil (Ananda, 2016). Proses pembuatan kerupuk 


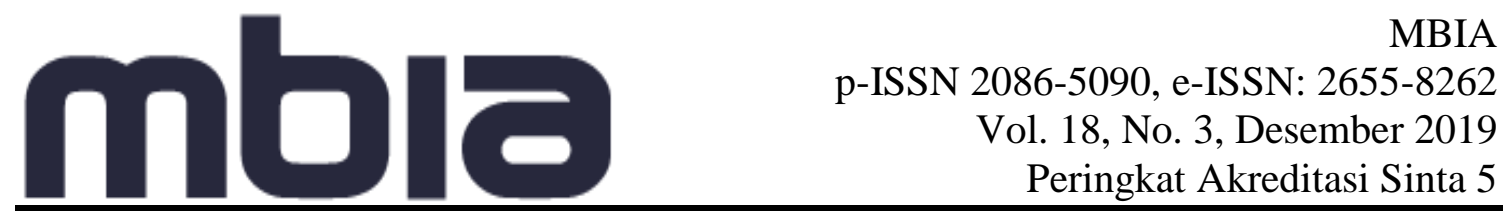

kemplang ini juga dikerjakan bersama beberapa anggota keluarga diantara mereka, dengan peralatan apa adanya, serta tanpa sistem administrasi dan keuangan yang tertata.

Pasar kerupuk kemplang sangat luas. Masyarakat sehari-hari mencari jenis makanan ini sebagai bagian dari keseharian mereka. Masyarakat juga sering menjadikan kerupuk kemplang ini sebagai suguhan dan buah tangan untuk keluarga yang datang dan oleh-oleh ketika bepergian ke daerah lain dengan kemasan sederhana. Padahal kemasan yang lebih baik juga memungkinkan kerupuk kemplang ini diminati pasar yang lebih luas. Bahkan sebagai bagian dari usaha membuat keragaman, bahan dasar kerupuk kemplang juga fleksibel dijadikan produk lain yang diminati masyarakat. Kualitas produk menjadi pertimbangan konsumen membeli (Fitriah dan Hendro, 2017).

\section{Literature Review}

Potensi pengembangan kerupuk kemplang di atas tentu menjadi masalah apabila pengelolaanya tetap dilakukan apa adanya. Berdasarkan data lapangan, identifikasi masalah ditemukan berdasarkan fungsi usaha sebagai berikut :

a. Aspek Produksi. Unsur produksi ditekankan pada masalah bahan baku dan peralatan. Ketersediaan ikan sebagai bahan baku(sepat, palau, sapil, dan lain-lain) tidak stabil. Pada pertengahan musim penghujan sampai menjelang kemarau sangat berlimpah (Mutiara, 2017), akan tetapi musim kemarau sampai menjelang musim penghujan berikutnya ketersediaannya terbatas sehingga mahal. Ketika ada ketersediaan ikan ini, produksi berlimpah. Peralatan berupa alat penyimpan ikan yang tersedia sangat sederhana dan dapat dimanfaatkan, akan tetapi kualitasnya menjadi turun.

b. Aspek Keuangan. Belum dilakukan sama sekali administrasi usaha secara teratur. Administrasi keuangan yang sederhana dapat menjadi kelemahan internal usaha (Joesyiana, 2017). Pada usaha ini semua pengadaan bahan, alat, upah pengelolaan, dan hasil penjualan dilakukan tanpa pencatatan sama sekali. Kondisi ini membuat pengusaha tidak dapat menghitung jumlah pengeluaran dan pemasukan sehingga meskipun usaha tetap berjalan tetapi tidak dapat dihitung keuntungannya. Akibat lebih lanjut, potensinya untuk berkembang sulit dipantau.

c. Aspek Pemasaran. Pasar kerupuk kemplang sangat luas, bahkan belum semuanya dapat dimanfaatkan dengan baik. Selama ini pelaku usaha hanya melayani penduduk sekitas sebagai pembeli.

d. Aspek Sumberdaya Manusia. Fungsi ini tampaknya tidak banyak menjadi kendala. Tenaga kerja yang digunakan pelaku usaha semuanya adalah anggota keluarga dan anggota masyarakat sekitar yang kemampuannya dapat mendukung keberlanjutan usaha kerupuk kemplang.

\section{Metodologi Penelitian}

Penelitian ini dilakukan pada Usaha Kerupuk Kemplang "Ibu Mai" yang beralamat di desa Pantai Kecamatan Sirah Pulau Padang Kabupaten Ogan Komering Ilir Sumatera Selatan. Penentuan lokasi dilakukan secara sengaja (purposive) dengan pertimbangan usaha ini telah dijalankan selama 6 tahun.

Data yang dikumpulkan adalah data primer yang diperoleh langsung dari uit penelitian. Teknik pengumpulan data yang digunakan adalah observasi dan wawancara. Observasi dilakukan sejak bahan baku ikan dipasok, disimpan, diolah, sampai dibeli konsumen. 


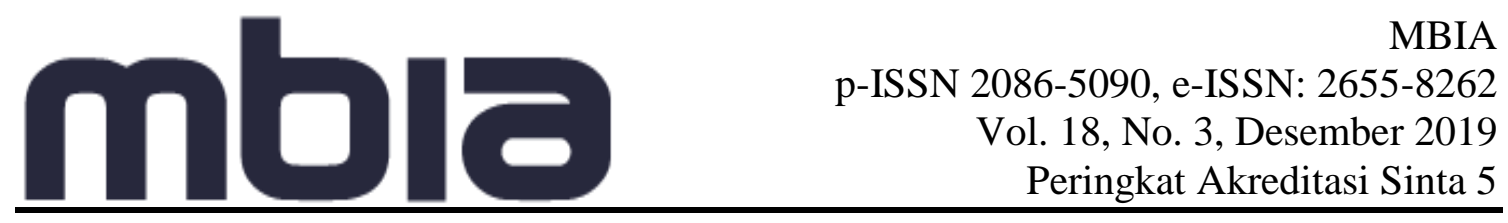

Wawancara dilakukan dengan pelaku usaha dan beberapa anggotanya yang terlibat dalam pengelolaan kerupuk kemplang Adapun teknik analisis yang digunakan adalah teknik analisis kualitatif dengan pendekatan analisis induksi.

\section{Hasil dan Pembahasan}

Berdasarkan data yang diperoleh dapat dilakukan pembahasan sebagai berikut :

a. Aspek Produksi.

Ketersediaan bahan baku berhubungan dengan masalah ketersediaan ikan. pertengahan Pada musim penghujan sampai menjelang kemarau keteresediaaan ikan sebagai bahan baku sangat banyak, akan tetapi musim kemarau sampai menjelang musim penghujan berikutnya ketersediaannya terbatas. Hal ini dapat diatasi dengan:

1) Menyiapkan tempat penyimpanan ikan yang layak. Selama ini pelaku usaha telah berusaha melakukan penyimpanan ikan menggunakan bekas kulkas dengan bantuan pendingin beberapa es batu yang dimasukkan secara menyebar. Proses pengawetan seperti ini tentu tidak optimal. Oleh karena itu diperlukan alat pendingin yang lebih layak. Peneliti telah memfasilitasi pelaku usaha dengan peralatan mesin giling dan freezer guna mulai memperbaiki aktifitas produksi.

2) Cara penyimpanan ikan juga dapat dilakukan dengan pembuatan ikan surimi. Ikan surimi dibuat menggunakan bahan baku ikan (dibuang kepala dan isis perut) yang dicuci menggunakan air es yang dicampur garam, dihaluskan/digiling kemudian disaring mengguakan kain kasa. Selanjutnya disimpan dalam freezer. Cara ini memungkinkan hasil penyimpanan dapat dilakukan lebih lama dan ikan tidak berbau atau pun berbah warna. Peneliti telah memberikan pelatihan pembuatan ikan surimi kepada pelaku usaha guna menjamin kontinuitas produksinya.

\section{b. Aspek Keuangan}

Selama ini pelaku usaha sama sekali tidak memiliki catatan administrasi keuangan. Semua bahan, peralatan, dan keperluan produksi (upah memperoleh ikan, membersihkan, mengolah, mengeringkan, dan lain-lain) dikeluarkan tanpa perencanaan dan perhitungan yang akurat. Hasil penjualan pun tidak tercatat. Semua transaski hanya berdasarkan ingatan. Kondisi ini tentu menyulitkan bahkan menghambat apabila akan dibuat target dan perhitungan keuntungan untuk keberlanjutan usaha. Unsur pengeluaran apa saja yang harus disiasati atau unsure pemasukan apa yang dapat dimaksimalkan tidak diketahui dengan pasti. Akibatnya perkiraan keuntungan tidak dapat dibuat, padahal trend keuntungan adalah syarat keberlanjutan sebuah usaha.

Keberlanjutan usaha juga memerlukan dukungan dana yang tidak harus berasal dari pelaku usaha sendiri. Pada uumumnya usaha kecil mengalami kesulitan modal dan hambatan pembiayaan (Arianty, 2017). Berbagai lembaga keuangan dapat membantu keberlanjutan usaha dengan memberikan pinjaman. Akan tetapi pinjaman tidak dapat diberikan lembaga keuangan tanpa ada laporan keuangan yang jelas. Usaha ini sama sekali belum memiliki sistem pencatatan administrasi keuangan. Oleh karena itu angkaangka yang dinyatakan ketika menjawab pertanyaan hanya berdasarkan kebiasaan dan ingatan saja. Oleh karena itu perlu disampaikan kepada pelaku usaha tentang :

1) Pentingnya pembuatan laporan keuangan. Administrasi keuangan harus dimiliki setiap usaha yang akan dipertahankan keberlanjutannya. Untuk itu diperlukan informasi tentang naik turunnya usaha yang dikelola lewat naik turunnya pendapatan dalam 
kurun waktu tertentu. Usaha yang berkembang tentu menjadi tujuan setiap pelaku usaha karena memungkinkan diperolehnya kesejahteraan bagi pemilik usaha serta orang-orang yang terlibat didalamnya.

2) Pencatatan Keuangan Sederhana untuk Bisnis Rumah Tangga. Pencatatan diperlukan agar kondisi keuangan usaha dapat dilihat secara jelas, usaha tidak terhenti, dan menjadi dasar pembuatan berbagai dokumen (pembiayaan, pajak, dan lain-lain)

3) Tahapan yang dilakukan untuk melakukan pencatatan bisnis. Prinsip utama dalam tahap ini adalah memisahkan keuangan pribadi dan keuangan usaha. Dokumen pendukung perlu disiapkan guna menjadi bahan dasar pembuatan catatan tentang pengeluaran dan pemasukan. Mengelola keuangan tidak sekedar mencatat masukan dan pengeluaran tetapi juga menggagas perkembangn usaha (Louis dan Setiawan, 2013).

Terhadap aspek keuangan ini peneliti juga telah memberikan contoh pembuatan laporan keuangan berikut memberikan pelatihan cara pembuatannya. Dengan cara ini diharapkan pelaku usaha mulai dapat mencermati perkembangan usahanya lebih baik.

\section{c. Aspek Pasar}

Usaha kerupuk kemplang termasuk usaha yang cukup berkelanjutan (Setiofano, dkk, 2017). Potensi pasar kerupuk ini dapat dikelompokkan menjadi :

1) Pasar sekitar lokasi usaha. Terdapat beberapa pelaku usaha kerupuk kemplang di daerah ini, meskipun demikian karena kerupuk kemplang adalah makanan khas yang biasa dimakan sehari-hari maka pasar dapat dikatakan selalu tersedia. Dalam pengamatan terlihat :

- Terkadang terdapat pembeli yang datang bukan untuk membeli kerupuk kemplang tetapi membeli kerupuk setengah jadi yang belum dikeringkan untuk dimakan sebagai camilan. Fenomena ini memunculkan ide keragaman produk, produk setengah jadi dan produk jadi.

- Pelaku usaha juga terkadang belum sepenuhnya dapat memenuhi permintaan pasar

2) Pasar luar desa. Dalam pengamatan dan wawancara juga diperoleh informasi bahwa pelaku usaha mendapatkan pesanan kerupuk kemplang untuk dibawa ke luar desa. Ini berarti dengan memperbaiki aspek pemasaran maka keberlanjutan usaha semakin menjanjikan. Perbaikan yang dimaksud dapat berupa :

- Perbaikan produk dalam hal kemasan, pencantuman merek, atau perbaikan kualitas pengelolaan bahan bakunya.

- Keragaman ikan dapat menjadi dasar keragaman produk yang berdampak pada nilai kerupuk yang dinilai lebih baik sehingga dapat dijual dengan harga yang lebih mahal. Widagdo dkk (2017) menyatakan bahwa harga tidak berpengaruh terhadap minat beli konsumen. Akan tetapi hal itu dimaksudkan untuk kerupuk kemplang yang belum dikembangkan. Pengembangan akan memberikan nilai lebih dan memberikan pengaruh terhadap harga.

- Pelaku usaha dapat menggunakan jasa perantara untuk lebih memperluas pasarnya.

- Promosi dapat berkembang sendirinya lewat informasi dari mulut ke mulut baik dilakukan oleh pembeli maupun perantara. Hal ini akan semakin memperluas pasar. 


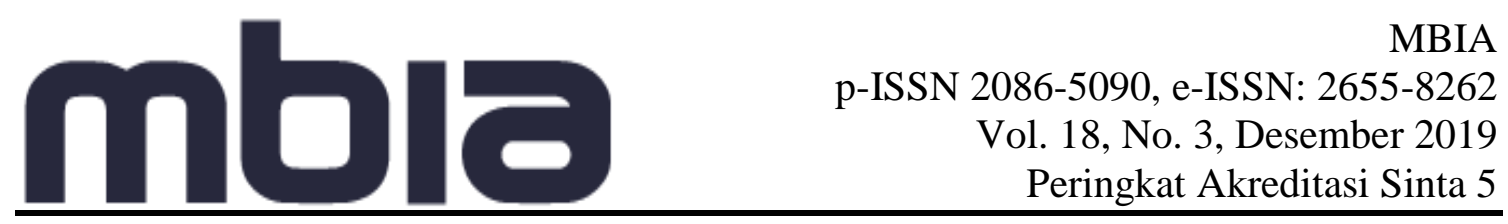

Hal-hal di atas perlu dipahami dan terus disosialisasikan kepada pelaku usaha. Pemahaman terhadap aspek ini akan mendorong semangat pelaku usaha untuk mengembangkan keberlanjutan usahanya dalam jangka panjang.

\section{d. Aspek Sumberdaya Manusia}

Saat ini sumberdaya manusia memang belum urgen untuk dibenahi. Semua anggota keluarga yang ikut terlibat dalam pengelolaan usaha telah menjalankan perannya masingmasing dengan baik. Meskipun demikian secara bertahap masing-masing harus diberikan pemahaman lebih baik tentang pentingnya keberlanjutan usaha. Dengan demikian semua memiliki semangat untuk terus bekerja lebih baik.

Masalah yang harus segera dilakukan adalah menyiapkan anggota keluarga yang harus segera belajar sekaligus menerapkan administrasi keuangan. Hal ini diperlukan agar tren perkembangan usaha dapat segera diketahui sehingga mulai terlihat langkah apa saja yang harus dilakukan untuk memaksimalkan hasil penjualan..

\section{Simpulan}

Berdasarkan hasil pembahasan dan langkah yang telah ditempuh, dapat disimpulkan sebagai berikut:

1. Aspek Produksi

Beberapa bantuan untuk mengatasi kendala produksi telah diberikan kepada pelaku usaha agar dapat menjalankan aktifitas produksinya lebih baik.

2. Aspek Keuangan

Contoh dan pelatihan pembuatan administrasi keuangan telah diberikan kepada pelaku usaha agar dapat mencermati perkembangan usahanya lebih baik

3. Aspek Pemasaran

Pemahaman tentang pentingnya pemasaran perlu terus dikomunikasikan kepada pelaku usaha untuk menjamin keberlanjutan usahanya.

4. Aspek Sumberdaya Manusia

Masalah penting dalam hubungannya dengan sumberdaya adalah menyiapkan anggota keluarga yang harus segera belajar sekaligus menerapkan administrasi keuangan.

\section{Daftar Pustaka}

Ananda, Riska. (2016) Peran Home Industri Dalam Meningkatkan Ekonomi Keluarga (Studi Kasus Home Industry Keripik di Kalurahan Kubu Gadang). JPM FISIP 3(2), $1-15$

Arianty, Nel. (2017). Analisis Usaha Industri Rumah Tangga Dalam Rangka Meningkatkan Pendapatan. Prosiding Seminar Hilirisasi Penelitian untuk Kesejahteraan Masyarakat, Lembaga Penelitian Universitas Negeri Medan 28 September 2017

Fitriah, Wani dan Omar Hendro. (2017) Tinjauan Usaha Kerupuk Kemplang Ikan Bilik Desa Lumpatan Kecamatan sekayu. Jurnal Abdimas Mandiri 1(2), 115-123

Joesyiana, Kiki.(2017) Strategi Pengembangan Industri Rumah Tangga Di Kota Pekanbaru. Jurnal Valuta 3(1), 159-172. 


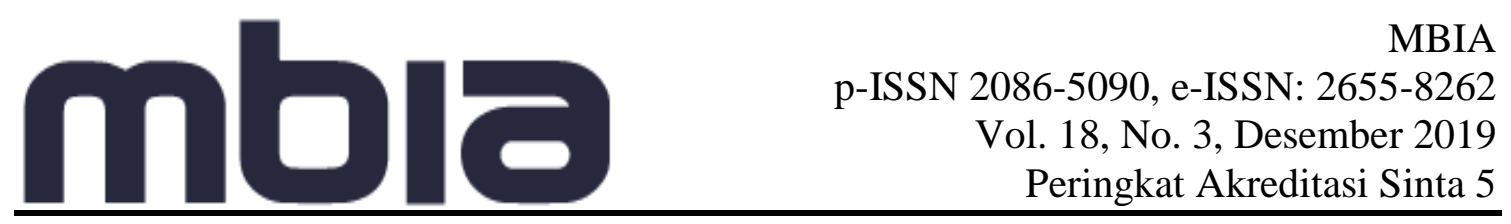

Louis, Nickson Bernhard dan Roy Setiawan. (2013) Pengelolaan dan Pengembangan BisnisIndustri Alat Rumah Tangga Plastik Pada Fungsi Sumber Daya Manusia Di PT Lestari Bambe Plastik. AGORA 1(1), 1-13

Mutiara, D. (2017)Keanekaragaman Spesies Ikan Di Sungai Padang Kecamatan Sirah Pulau Padang Kabupaten Ogan Komering Ilir Provinsi Sumatera Selatan. SAINMATIKA, 14(2), 107-111.

Widagdo, Herry, Charisma Ayu P, Raisa Pratiwi. (2017) Analisis Strategi Pemasaran Terhadap Minat Beli Kerupuk Kemplang UKM Palembang. Prosisding SEMNAS IIB Darmajaya Lembaga Penelitian Penembangan Pembelajaran \& Pengabdian Keada Masyarakat 25 Oktober 2017

Setiofano, Fadel Wahyu, Herpandi, Indah Widiastuti. (2017) Analisis Keberlanjutan Pengelolaan Kerupuk Ikan di Kabupaten Ogan Ilir Sumatera Selatan. Jurnal Teknologi Hasil Perikanan 6(2), 153-162

\section{Acknowledgement}

Terima kasih penulis ucapkan kepada Kementrian Riset, Teknologi dan Pendidikan Tinggi yang telah memberikan dana hibah penelitian dosen Tahun 2018/2019 kepada penulis sehingga penulis dapat menyelesaikan penelitian dan menghasilkan artikel ini.

\section{Copyright Disclaimer}

Copyright for this article is retained by the author(s), with first publication rights granted to the journal. 